\title{
CACNA1G Gene
}

National Cancer Institute

\section{Source}

National Cancer Institute. CACNA1G Gene. NCI Thesaurus. Code C105856.

This gene is involved in calcium transport. 